\title{
Enhancing Reading Skill Through Apptone Learning
}

Rachel Nyanamoney Moses, Agatheswari Paneerselvam, Melor Md Yunus, Harwati Hashim, Haida Umiera Hashim

To Link this Article: http://dx.doi.org/10.6007/IJARBSS/v11-i12/11761

DOI:10.6007/IJARBSS/v11-i12/11761

Received: 04 October 2021, Revised: 05 November 2021, Accepted: 18 November 2021

Published Online: 01 December 2021

In-Text Citation: (Moses et al., 2021)

To Cite this Article: Moses, R. N., Paneerselvam, A., Yunus, M. M., Hashim, H., \& Hashim, H. U. (2021). Enhancing Reading Skill Through Apptone Learning. International Journal of Academic Research in Business and Social Sciences, 11(12), 238-248.

\section{Copyright: (c) 2021 The Author(s)}

Published by Human Resource Management Academic Research Society (www.hrmars.com)

This article is published under the Creative Commons Attribution (CC BY 4.0) license. Anyone may reproduce, distribute, translate and create derivative works of this article (for both commercial and non0-commercial purposes), subject to full attribution to the original publication and authors. The full terms of this license may be seen at: http://creativecommons.org/licences/by/4.0/legalcode

Full Terms \& Conditions of access and use can be found at http://hrmars.com/index.php/pages/detail/publication-ethics 


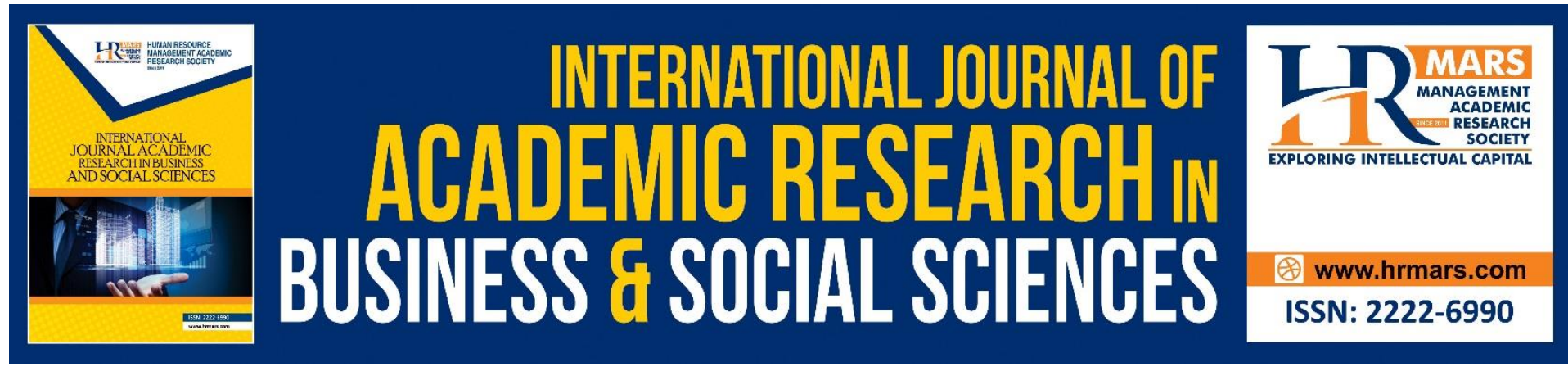

\title{
Enhancing Reading Skill Through Apptone Learning
}

\section{Rachel Nyanamoney Moses, Agatheswari Paneerselvam, Melor Md Yunus, Harwati Hashim, Haida Umiera Hashim} Faculty of Education, Universiti Kebangsaan Malaysia, Bangi, Selangor, Malaysia Email: rachelmoses85@gmail.com,aga_paru@hotmail.my,melor@ukm.edu.my, harwati@ukm.edu.my, haidaumiera@gmail.com

\begin{abstract}
Digitalization takes up a stronghold across all fields in the world including teaching and learning. In line with that, an attempt was made to introduce an innovative method in connecting the younger generations' reading skill with WhatsApp, the current trend of social media. Reading skill acts as one of the imperative language skills to ace the English language. The lower elementary international school students, who originated from non-English background countries, battle and confront trouble in reading due to their low proficiency in the language. Therefore, this paper aims to investigate the use of Apptone (voice messages) to improve students' reading skill and enhance the students' motivation towards reading skill. Apptone learning through WhatsApp was designed and executed among 29 lower elementary international school students who are from China, Japan, Yemen, Sudan and Jordan. This attempt has been carried out at an international school situated in Selangor. The teacher sent short stories to the parents via the WhatsApp group and the stories were read by the students. Then, the recorded version was sent to the teacher personally via the same platform. Subsequently, this attempt has successfully increased the students' interest and motivation in reading while the findings indicated the improvement of the students' reading skill. In conclusion, Apptone learning is an encouraging yet beneficial method for lower elementary international students in enhancing their reading skill.
\end{abstract}

Keywords: Apptone Learning, Reading Skill, Whatsapp, International School, Lower Elementary Students

\section{Introduction}

Digitalization takes up a stronghold across all fields in the world including teaching and learning, especially in the context of language learning (Buck, 2017). As language plays a vital role in human communication, it becomes a bridge among humans that connects each other. In fact, globalization has created a need for a common language platform in which the English language has become one of the languages used internationally by various countries and communities to interact and build their businesses, thus, it is needed to face the 21st-century demands (Paneerselvam \& Mohamad, 2019). Therefore, English education is exceptionally vital to be taught and learned by the students. 
Speaking about language, one can never deny the importance of acquiring language skills. In the context of education, a student needs to know how to read, write, speak and listen. Particularly, reading is the basic input to process and master the language. Reading skill is also referred to as an instrument of interaction in literacy via the writing form (Ismail, Syahruza \& Basuki, 2017). Precisely, reading skill acts as one of the imperative language skills to ace the English language.

The targeted lower elementary international school students are originated from non-English background countries. These Year 2 and Year 3 students are from an international elementary school which is located in Selangor, Malaysia. The students are in a battle and confront trouble in reading due to their low proficiency in the language. This issue needs to be tackled productively as this may lead the students to stand troubles in their academics as stated by (Moses and Mohamed, 2019). In line with that, an attempt was made to introduce an innovative method in connecting the younger generations' reading skill with Apptone Learning. The word Apptone was derived from the word "WhatsApp" and the phrase "reading tone". WhatsApp was chosen as it is the current trend of social media, hence, it has been used as a platform to enhance students' reading skill.

In addition, this innovation serves as a contribution to all three different parties such as the teachers, students and also the parents. The teachers would find it as a new method to involve the younger ones while the students certainly feel excited to record their voices and share with their teachers. On the other hand, the parents would also be able to track their child's reading progress effectively which means parents play an important role in the process too. Therefore, this paper aims to investigate the use of Apptone (voice messages) to improve students' reading skill and enhance the students' motivation towards reading skill. On the whole, Apptone learning acts as an innovative way of connecting the younger ones with social media in a healthier, friendlier yet meaningful way.

\section{Literature Review \\ Reading skill}

Reading skill is one of the language skills which is important to be acquired. In other words, reading skill is also known as literacy. Reading acts as the basic input skill to master the language as a language mastery will not be successful without reading competency (Cagri, 2012). Furthermore, reading is not just the ability to read something, but also to comprehend and understand the text as what is being conveyed by the author as mentioned by (Evdokimos and Eleni, 2014). People at different age group and community have a different level of reading skill, while the majority of people can read but understanding and comprehension is still something that is lacking as authors could come from a different background or education levels which could cause a disparity when it comes to conveying information, emotion or message via a written form.

Besides, many researchers also claimed that reading competency would contribute to the development of other language skills as well such as speaking and writing. (Williams, 1984; Krashen and Terrell, 1989). Reading helps in building vocabulary knowledge which is useful in developing speaking competency (Cagri, 2012). Nevertheless, among the other three language skills such as writing, speaking and listening, reading is the most vital skill for students especially to those who are from non-English background countries as stated by (Melor, Nurulhusna and Ashairi, 2020). However, these students find it difficult to excel in reading the English language as it is a new language which they have less exposure to. Therefore, it seems to be even more difficult for the students to acquire it and this leads to 
many other learning issues such as negative experiences and low motivation which eventually holds them back from participating in the lessons (Wheeler, 1946; Stanovich, 1986; Cambria and Guthrie, 2010). According to Mokhtar (2010), the issue of reading skill is caused by the inefficiency of reading at a young age. Hence, it is very important to tackle the problem at an early stage in order to provide a solid foundation of the language.

\section{Innovative Ways of Improving Reading Skill}

Since reading skill is important as discussed earlier and motivation plays a vital role here, it is also equally important to explore the ways to help weak students in not only spiking up their reading motivation level but also to help them develop their reading skill. Following the thread, Chen (2011); Klimova and Zamborova (2020) proved that the integration of digital resources into paper-based reading activities would certainly help in developing reading skill in terms of comprehension. The scaffolding strategy used here has benefitted the targeted students of the study in comprehending challenging articles.

On the other hand, text-to-speech software implemented by Robert et al (2012) also proved the improvement of the reading skill in both their pilot studies involving high school struggling readers. This intervention has a positive impact on the reading speed of the students as they can also adjust the speed accordingly, thus, allowing time to think while reading. Imam (2020) suggested that the implementation of the SQ3R method is effective in improving students' reading skill. SQ3R literally stands for surveys, questions, read, recite and review. The researcher proved that this method is a way for the students to build their creativity and advance themselves to a higher stage of reading by exploring each stage of the process effectively.

Other than that, the WhatsApp platform was also used by Susanti (2020) to improve reading skills among school students. The result showed that $76 \%$ of students agreed and feel comfortable in using WhatsApp to improve their reading skill. The researcher has mentioned that students have improved in their reading skill as they could explore new vocabularies, hence, they felt motivated to participate actively and they became brave to read as well. From this research, it shows that WhatsApp has improved the students' reading skill and it is recommended to be used to produce fruitful learning. However, there is a very limited study carried out in this subject area involving the lower elementary students, specifically in an international school context. Therefore, this study has undertaken an attempt to fill this gap in the research field.

\section{Impact of Motivation on Reading Skill}

Motivation is a way to inspire someone to achieve a goal. Motivation can make changes on students' reading skill before and after and it is seen as a precondition and a required element for students' participation in learning as it is a necessary element stated by (Sitwat and David, 2012). Through motivation, students will not only participate in a learning process but there is a chance for them to achieve good results academically (Picton, 2014). In accordance with that, Ahmadi et al (2013) have explored the connection between reading skill and motivation and found that motivation has led the students to put in their effort and interest into practice. The changes in their motivation level have helped the students to know that they have borne fruits. He also concluded that students with higher motivation have scored higher marks in the reading comprehension exam.

Apart from that, there are also researchers who have conducted a study around this area and proved that motivation, both intrinsic and extrinsic motivation, have a positive impact on 
students' reading skill such as Wang and Guthrie (2004); Lepper et al (2005); Logan (2011). As stated by Logan (2011), motivated students will continue to strive for comprehension development through their reading habits as motivation plays a strong role in students' reading improvement especially among the weak students. The impact of motivation in reading has significantly been associated with reading skill. Based on the past studies discussed earlier, it is clearly showing that motivation plays a vital role in students' reading skill as students with a higher level of motivation will progress even more compared to students with a lower level of motivation as stated by (Ahmadi, 2017). In fact, Chen et al (2017) also concluded that low motivation and interest affects the students' reading comprehension.

\section{Reading with Metacognition}

As mentioned earlier, this study has chosen the lower elementary international students, who are in Year 2 and Year 3 for the implementation of the innovation of the study which is Apptone learning. Based on the earlier discussions above, reading is often related to the understanding of what is read followed by pronunciation, reading speed and vocabulary respectively. Since this study is involving non-English background students who perceive a low proficiency of English, it is important to start from the basics.

Therefore, this study has used the metacognition theory by John Flavell (1979), who is believed to be the 'father of the field' and focuses only on the pronunciation, vocabulary and spelling, and the reading tone of the students. According to John Flavell (1979), metacognition refers to "thinking about thinking." Basically, it is a way to guide and train students in "learning how to learn." This strategy typically involves attention, memory, sequencing and processing skills in learning. In accordance with that, the present study has adopted and adapted the reading with metacognitive diagrams from Gemm Learning.com as shown in Diagram 1 below.

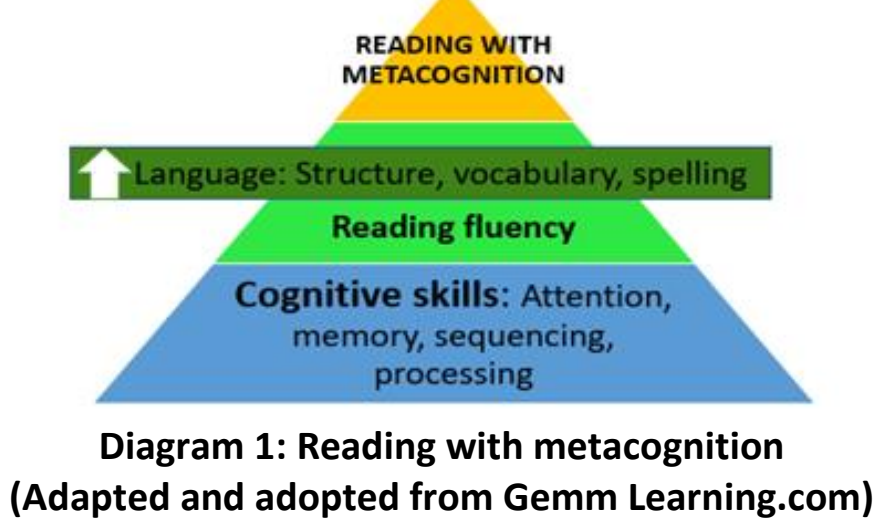

According to the diagram above, the students will be focusing on cognitive skills while practicing their reading. It helps them to pay attention, think and recall the lessons taught by the teacher in terms of the vocabularies and the pronunciations. This would eventually proceed them to the next level, which is the reading fluency by giving more close attention to the structure, vocabulary and spelling, which contributes to the end product, the targeted language. As the students are exposed to this theory, undoubtedly they are also being trained to self-monitor and self-reflect their learning process. 


\section{Methodology}

\section{Research Design}

This paper has employed an action research mode, specifically upholding the individual research design, whereby a new innovation has been tested among the targeted students in order to enhance their reading skill. Apptone learning has been implemented to increase their motivation and participation in the reading activity in a new meaningful way. Therefore, the pre-reading and post-reading status of the students have been observed.

\section{Participants}

In this study, purposive sampling was used. 29 lower elementary international school students who are from China, Japan, Yemen, Sudan and Jordan have been chosen for this study. These Year 2 and Year 3 students (aged from 6 to 10) consist of 11 boys and 18 girls and they are from an international elementary school which is located in Selangor, Malaysia. These students have low proficiency in the English language and they struggle in reading. Therefore, the students are finding it hard to understand and read any materials such as a passage, a story or an instruction and this results in low achievement academically. At the same time, the students feel demotivated and less interested to participate in reading activities in the class, thus, they feel left out in the lessons.

\section{Research Instrument}

As this study implements an innovative approach in language teaching, the instrument used refers to the platform used for the implementation process. WhatsApp, being the current trend of social media, has been chosen as the platform for the study. It is a new approach to connect the lower elementary students with social media with the help of their parents. Besides, observation, being the second instrument used in the study, has been opted to record the outcome of the study.

\section{Research Procedure}

Knowing that the lower elementary students are facing difficulty in reading, the implementation of Apptone learning has been carried out with the help of the students. The process began with lesson delivery as per the content and vocabulary of the topic taught. This includes the explanation of meanings, definitions, synonyms and giving some examples during the lesson delivery period. Then, a short story was sent to the parents via the WhatsApp parents' group with the announcement and time frame by the teacher at the end of each topic. Then, the students practiced their reading at home by following the metacognitive theory. Once they are prepared, they seek help from their parents to record their reading and send back the recording to the teacher personally via the same platform. At the end of the process, the teacher conducted a feedback and rewards session to encourage and motivate the students for their next attempts. This process has been carried out for three months (comprises 4 topics) to observe the students' reading skill.

\section{Data Collection and Analyses}

The improvement of 29 lower primary students have been observed and recorded in terms of students' participation, reading improvement, students' interest and motivation, and parents' satisfaction. All data collected using the same platform which is WhatsApp and has been presented in a bar graph for a clearer view. The responses have been screenshot for further analysis to be done. 


\section{Results and Discussion}

This action research was carried out successfully among the international elementary school students who are in Year 2 and Year 3. The overall students' reading skill progress and parents' feedback were observed and recorded through WhatsApp. The data has been converted into a bar graph as shown in Figure 1 below. Following the thread, the screenshots have also been attached as follows.

\section{Students' Participation}

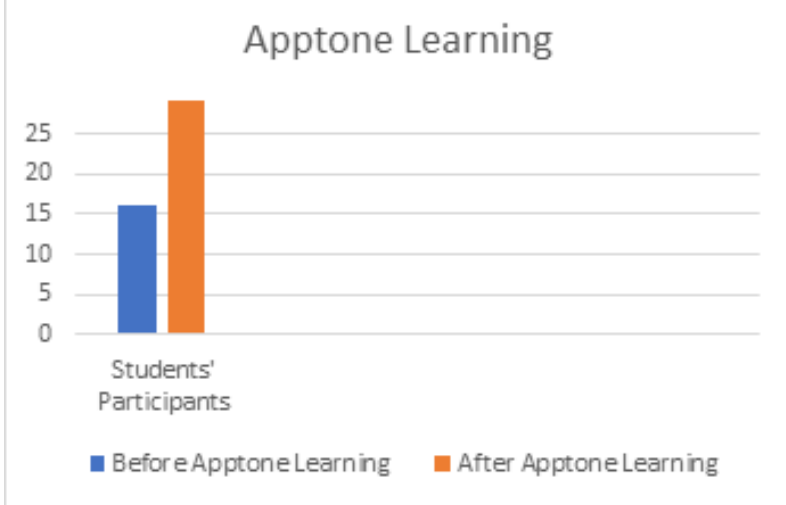

Figure 1: Pre and post impacts of Apptone implementation towards students' reading skill

Figure 1 above shows the data collected through observation on the implementation of Apptone learning. It can be seen that the 29 lower primary students have participated actively compared to the reading activities that have been done in class before the implementation of Apptone learning. The number of students who sent in their recording spikes up from 16 to 29 where it shows their active participation. As said by Ahmadi et al, (2013), motivation towards reading skill has helped the students to have more interest in reading skill with students' active participation. Students were less active in reading activity may be due to the normal way of teaching and practicing reading in the class. At the same time, the teachers were also pushed to complete the syllabus on time and therefore, less attention was given to those students' reading skill. Apptone learning allows preparation time for the students to practice their reading and simultaneously, the teacher too has ample time to check on the students' reading and tackle their problems accordingly. Therefore, a stress-free environment is created through the implementation of Apptone learning. According to many researchers, a stress-free environment is key for students to succeed in their learning.

\section{Students' Reading Improvement}

Apptone learning has proven its effectiveness in terms of the students' reading improvement. Not only in terms of participation, but the students reading has also improved through Apptone learning. In a research carried out by Chen (2011); Koronina et al (2016), it was found that students' reading skill has improved by using digital resources. This is where exactly the theory of the study comes in whereby the students remember and recall the lesson delivered by the teacher in order to read the text given effectively. Some students also recorded the same story a few times to get it right as shown below in Figure 2 and 3 . In this way, it is clear that the students have also practiced self-reflection strategy to improve their reading skill, thus, they are not afraid of making mistakes. 


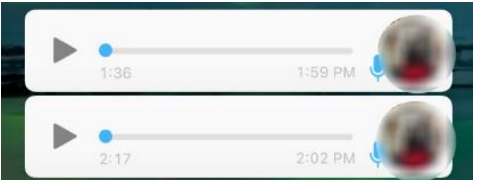

Figure 2

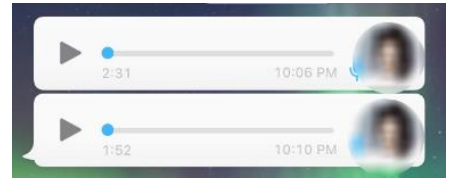

Figure 3

\section{Students' Interest and Motivation}

On the other hand, the students were so interested in the reading activity when they began to use Apptone learning. This is because technology changed the lives of students inside and outside the classroom to the degree that they use technology to boost their learning experiences in the classroom as said by Hashim et al, (2017). At the same time, students were also excited during the feedback and rewards session. They felt excited when the teacher chose and shared their recording with the others in the class as the best for the week. At the same time, the session also spiked up the students' motivation to do better in their next attempts which also contributed to the participation level mentioned earlier. Moreover, this is what Krashen (1985) mentioned as once the students' affective filter is lowered, the students can perform better. Figure 4,5 and 6 below show that the students were interested in the activity which they have expressed through WhatsApp.

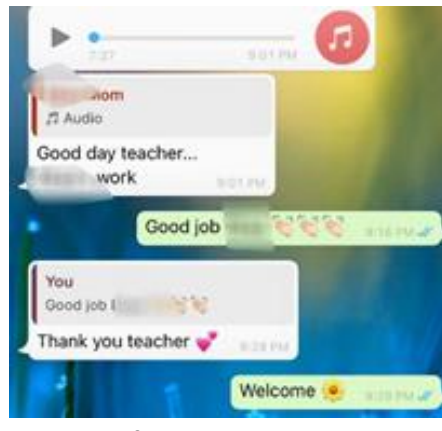

Figure 4

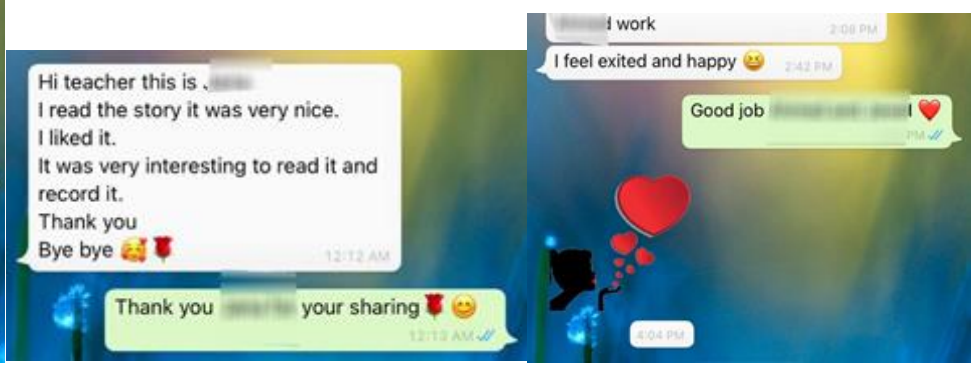

Figure 5

Figure 6

The students shared their interest by saying "I liked it", "I feel excited and happy" and "It was very interesting to read and record it." This certainly shows that Apptone learning has certainly boosted students' reading interest and motivation as they continuously strive to improve their reading skill and this finding is similar to the findings of (Chen et al., 2017; Ahmadi, 2017).

\section{Parents' Satisfaction}

Since Apptone learning requires parents' involvement in the teaching and learning process, it was found that parents have a high satisfaction on their child's learning especially on their reading improvement. The parents have expressed their satisfaction via WhatsApp when they were requested to give some feedback on the implementation. Figure 7, 8 and 9 below shows that the parents support the teacher's idea of using social media in teaching as it is improving the students' level of reading. Some parents' mentioned that Apptone learning is a "good initiative" while a parent responded as "...I am busy but I try to help and record for her because she gets excited about it." Apparently, it is clear that this innovation not only allows the parents to track their child's reading progress but it also helps to create a lovable strong bond between the busy parents and their child. In fact, parents' involvement in their child's learning process is proven to be effective in resulting in a good academic improvement as proven by (Xu et al., 2010; Emerson et al., 2012; Wilder, 2014). 


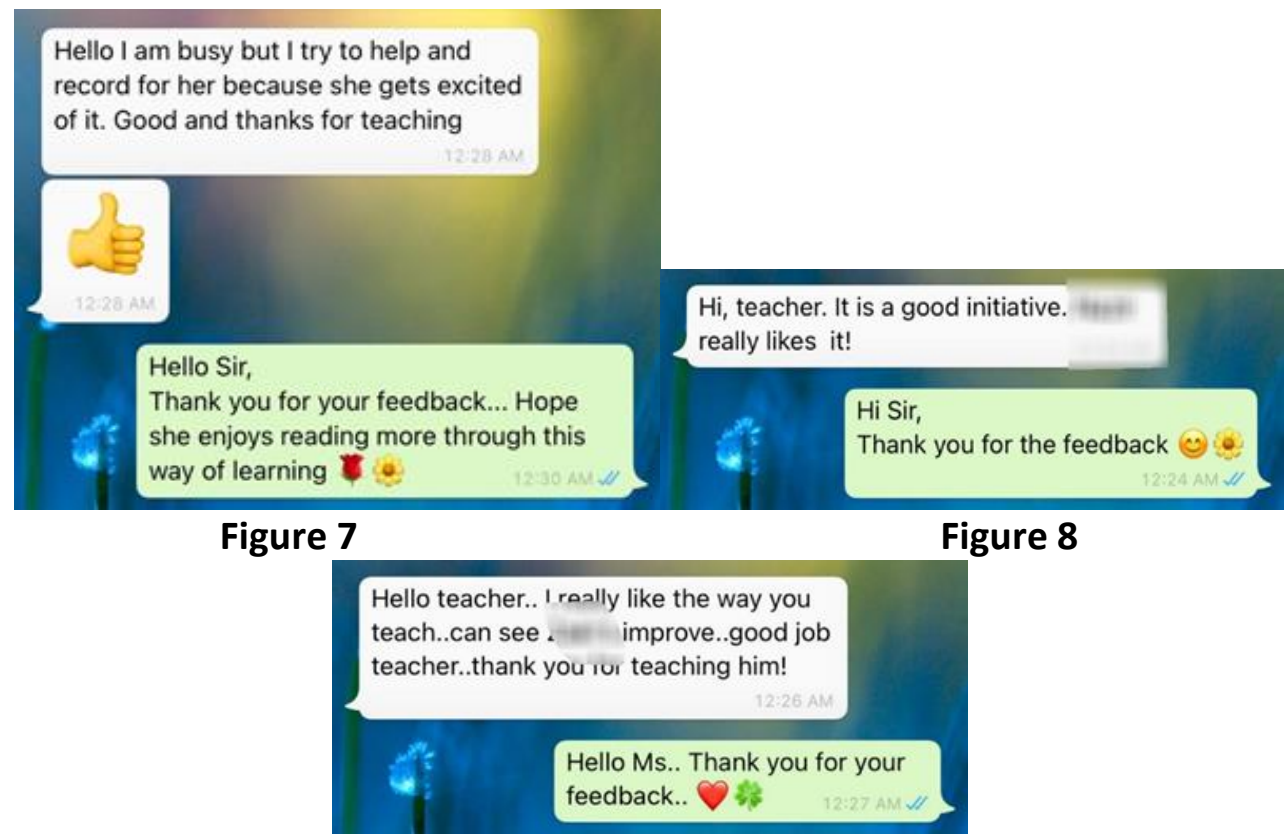

Figure 9

\section{Conclusion and Recommendation}

In an attempt to introduce an innovative method in connecting the younger generations' reading skill with WhatsApp, Apptone learning was designed to tackle the lower elementary international school students' reading difficulty. The targeted students who are from nonEnglish background countries face difficulties in reading due to their low proficiency in the language. Therefore, this paper aims to investigate the use of Apptone (voice messages) to improve students' reading skill and enhance the students' motivation towards reading skill. The students' improvement in reading skill has been recorded with regard to four aspects such as students' participation, reading improvement, interest and motivation, and parents' satisfaction. Subsequently, this attempt has successfully increased the students' interest and motivation in reading while the findings indicated the improvement of the students' reading skill. However, this study only focused on the lower elementary students who are in Year 2 and Year 3. Therefore, future researchers can use WhatsApp as a platform to teach or improve the different levels of students from a different school context. The future study can also be done on examining the level of improvement with regard to gender and other elements of reading such as reading comprehension. In conclusion, Apptone learning is an encouraging yet beneficial method for lower elementary international students in enhancing their reading skill.

\section{Acknowledgement}

The authors would like to acknowledge Universiti Kebangsaan Malaysia under research grant No. GG-2020-014 and GG-2020-024.

\section{References}

Ahmadi, M. R. (2017). The Impact of Motivation on Reading Comprehension. International Journal of Research in English Education, 2(1), 1-7. doi:10.18869/acadpub.ijree.2.1.1

Ahmadi, R. A., Ismail, H. N., \& Abdullah, M. K. (2013). The relation between students' reading motivation and reading comprehension. Journal of Education and Practice, 4(18), 8-17. 
Aivazoglou, E., \& Griva, E. (2014). Reading Skills and Strategies: Assessing Primary School Students' Awareness in L1 and EFL Strategy Use. International Journal of Applied Linguistics \& English Literature, 3(5), 239-250. http://dx.doi.org/10.7575/aiac.ijalel.v.3n.5p.239.

Mart, C. T. (2012). Developing Speaking Skills through Reading. International Journal of English Linguistics, 2(6),91-96. doi:10.5539/ijel.v2n6p91.

Cambria, J., \& Guthrie, J. T. (2010). Motivating and engaging students in reading. The NERA Journal, 46(1),16-29.

Chen, N.-S., Teng, D. C.-E., Lee, C.-H., \& Kinshuk. (2011). Augmenting paper-based reading activity with direct access to digital materials and scaffolded questioning. Computers \& Education, 57, 1705-1715. doi:10.1016/j.compedu.2011.03.013.

Chen, L. L., Yunus, M. M., \& Maarof, N. (2017). Factors affecting ESL reading comprehension of Malaysian secondary school students. In International Conference on Education (ICE2) 2018: Education and Innovation in Science in the Digital Era (pp. 542-547).

Emerson, L., Fear, J., Fox, S., \& Sanders, E. (2012). Parent engagement in learning and schooling: lessons from research. A report by the Australian research alliance for children and youth. Canberra: Family-School and Community Partnerships Bureau.

Flavell, J. H. (1979). Metacognition and cognitive monitoring: A new area of cognitivedevelopmental inquiry. American Psychologist, 34, 906-911.

Hashim, H., Embi, M. A., \& Ozir, A. M. (2017). Mobile-assisted Language Learning (MALL) for ESL Learners: A Review of Affordances and Constraints. Sains Humanika, 9:1-5, 45-50

Aziz, I. N. (2020). Implementation of SQ3R Method in Improving the Students' Basic Reading Skill. EDUCATIO: Journal Of Education, 5(1), 97-106.

Ismail, H., Syahruza, J. K., \& Basuki. (2017). Improving the Students' Reading Skill through Translation Method. Journal of English Education, 2(2), 124-131.

Klimova B., \& Zamborova K. (2020). Use of Mobile Applications in Developing Reading Comprehension in Second Language Acquisition -A Review Study. Education Sciences, 10(321), 1-11.

Korovina, S., Pushkina, A., \& Gurova, N. (2016). Online Blogs in the Process of Development of Students' Reading Skills, 298-305 http://dx.doi.org/10.15405/epsbs.2016.12.38

Krashen, S. (1985). The Input Hypothesis. London: Longman.

Krashen, S. D., \& Terrell, T. D. (1989). The Natural Approach: Language Acquisition in the Classroom. Pergamon: Prentice Hall.

Lepper, M. R., Henderlong Corpus, J., \& Iyengar, S. S. (2005). Intrinsic and extrinsic motivational orientations in the classroom: Age differences and academic correlates. Journal of Educational Psychology, 97(2), 184-196.

Logan, S., Medford, E., \& Hughes, N. (2011). The importance of intrinsic motivation for high and low ability readers' reading comprehension performance. Learning and Individual Differences, 21, 124-128. doi:10.1016/j.lindif.2010.09.011.

Marc, F. B. (2017). Gamification of Learning and Teaching in Schools - A Critical Stance. International journal of media, technology and lifelong learning, 13(1), 35-54.

Moses, R. N., \& Mohamad, M. (2019). Challenges Faced by Students and Teachers on Writing Skills in ESL Contexts: A Literature Review. Creative Education, 10, 3385-3391. https://doi.org/10.4236/ce.2019.1013260. 
Paneerselvam, A., \& Mohamad, M. (2019). Learners' Challenges and English Educators' Approaches in Teaching Speaking Skills in an ESL Classroom: A Literature Review. Creative Education, 10, 3299-3305. https://doi.org/10.4236/ce.2019.1013253.

Picton, I. (2014). The Impact of ebooks on the Reading Motivation and Reading Skills of Children and Young People: A rapid literature review, London: National Literacy Trust.

Saeed, S., \& Zyngier, D. (2012). How Motivation Influences Student Engagement: A Qualitative Case Study. Journal of Education and Learning, 1(2), 252-267. http://dx.doi.org/10.5539/jel.v1n2p252.

Stanovich, K. E. (1986). Matthew effects in reading: Some consequences of individual differences in the acquisition of literacy. Reading Research Quarterly, 21, 360-407.

Susanti. (2020). The Use of WhatsApp in Reading Lesson at the STMIK Pontianak, West Kalimantan, Indonesia. Jurnal Indonesia untuk Kajian Pendidikan, 5(1), 57-74.

Wang, J., \& Guthrie, J. T. (2004). Modeling the effects of intrinsic motivation, extrinsic motivation, amount of reading, and past reading achievement on text comprehension between U.S. and Chinese students. Reading Research Quarterly, 39(2), 162-186.

Wilder, S. (2014). Effects of parent involvement on academic achievement: a meta-synthesis. Educational Review, 66, 377-397. http://dx.doi.org/10.1080/00131911.2013.780009.

Williams, E. (1984). Reading in the Language Classroom. London: Macmillan Publishers Ltd.

Yunus, M. M., Yaacob, N., \& Suliman, A. (2020). The Use of Electronic Frog VLE in Assisting Reading Comprehension Activities. Universal Journal of Educational Research, 8(3), 879887. https://doi.org/10.13189/ujer.2020.080319.

Xu, M., Benson, K. S. N., Mudrey-Camino, R., \& Steiner, R. P. (2010). The relationship between parent involvement, self-regulated learning, and reading achievement of fifth graders: a path analysis using the ECLS-K database. Social Psychology of Education: An International Journal, 13, 237-269. http://dx.doi. org/10.1007/s11218-009-9104-4. 